\title{
Vote value disparity and judicial review in Japan
}

\section{Disparidade do valor do voto e revisão judicial no Japão}

\author{
YUICHIRO TSUJ' \\ University of Tsukuba (Japan) \\ gobear007@gmail.com \\ Recebido/Received: 18.04.2018 / April 18 ${ }^{\text {th }}, 2018$ \\ Aprovado/Approved: 26.04.2018 / April 26 ${ }^{\text {th }}, 2018$
}

\section{Abstract}

This study aims to propose a discussion on vote value disparity and judicial review in Japan. The starting point of this analysis is the 2015 ruling by the Japanese Supreme Court on the disparity in the number of members in the House of Representatives following the general elections of December 2014. According to the Japanese Constitution, the value of the votes should be equal to the total number of voters. It was requested to the Supreme Court that the results of the 2014 elections for the House of Representatives were considered null and void. The article analyses the current Diet, the Japanese electoral system, the Japanese judicial review and the relation between representatives and voters. Then, it focuses on $l k$ en-Jotai doctrine on "unconstitutional state or condition" about the irregularities with the process, as well as the 2015 reform and the Supreme Court's decision. It concludes, amongst other things, that the analyzed decision used the political question theory, and that the autonomy and discretion of the cabinet should have been considered. The methodology of the study is bibliographic and jurisprudential analysis on the theme.

Keywords: vote value disparity; judicial review; Japanese election; Iken-Jotai doctrine; Japanese Supreme Court.

\section{Resumo}

Este estudo tem como objetivo propor uma discussão sobre a disparidade do valor do voto e a revisão judicial no Japão. O ponto de partida desta análise é a decisão de 2015 do Supremo Tribunal japonês sobre a disparidade no número de membros na Câmara dos Representantes após as eleições gerais de dezembro de 2014. De acordo com a Constituição japonesa, o valor dos votos deve ser igual ao número total de eleitores. A Suprema Corte japonesa foi demandada para que os resultados das eleições de 2014 para a Câmara dos Representantes fossem considerados nulos e sem efeito. $O$ artigo analisa o atual regime, o sistema eleitoral japonês, a revisão judicial japonesa e a relação entre representantes e eleitores. Em seguida, enfoca a doutrina Iken-Jotai sobre "estado ou condição inconstitucional", sobre as irregularidades com o processo, bem como sobre a reforma de 2015 e a decisão da Suprema Corte. Conclui, entre outras coisas, que a decisão analisada utilizou a teoria das questões políticas e que a autonomia e discrição do gabinete deveriam ter sido consideradas. A metodologia do estudo é a análise bibliográfica e jurisprudencial sobre o tema.

Palavras-chave: disparidade de valor de voto; revisão judicial; eleição japonesa; doutrina lken-Jotai; Suprema Corte do Japão.

Como citar esse artigo/How to cite this article: TSUJ, Yuichiro. Vote Value Disparity and Judicial Review in Japan. Revista de Investigações Constitucionais, Curitiba, vol. 5, n. 2, p. 57-89, mai./ago. 2018. DOI: 10.5380/rinc.v5i2.58989.

"Associate Professor at Graduate School of Humanities and Social Science (legal major) at the University of Tsukuba (Tsukuba, Japan). Juris Doctor at University of California, Berkeley Scholl of Law J.S.D Program. Member of Japanese Public Law Association, I-Con and Asian Law Institute. E-mail: gobear007@gmail.com. 


\section{CONTENTS}

1. Introduction. 2. The constitutional drafting period and organization of the current Diet. 2.1. The amendment of the Meiji Constitution. 2.2. General elections under the Meiji Constitution and the current Diet. 3. Electoral system. 3.1. The Tomabechi case and the House of Representatives. 3.2. Reform of the House of Representatives. 3.3. The purpose of the House of Councilors. 3.4. Reform of the House of Councillors. 4. Major decisions and judicial review. 4.1. Japanese judicial review and elections. 4.2. The 2009, 2012, and 2014 decisions for the House of Councillors. 4.3.The 2011, 2013, and 2015 decisions for the House of Representatives. 5. The representative and the voters. 5.1. The mission of the representative. 5.2. Political party control and discipline. 6. Iken-Jotai doctrine in Japan. 6.1. The beginning of IkenJotai in a 1976 decision. 6.2. The 2005 decision for voting rights outside of Japan. 6.3. The 2015 reform and the Supreme Court decision. 7. Conclusion. 8. References.

\section{INTRODUCTION}

In November 2015, the Japanese Supreme Court ruled that there was disparity in the number of members in the House of Representatives following the general elections of December 2014. The plaintiff argued that the results of the 2014 elections for the House of Representatives were null and void. The value of the votes should be equal to the total number of voters, according to Articles 14 and 44 of the Japanese Constitution. The vote value disparity has created controversy through several cases since the Japanese Constitution was established.

The Japanese Supreme Court has repeatedly used a rather obscure doctrine called Iken-Jotai, or an "unconstitutional state or condition," which explains that, althou$\mathrm{gh}$ an election is effective, it is nevertheless an illegal and unconstitutional process at the time of election as per the equality before the law doctrine of Articles 14 and 44 of the Japanese Constitution. This unconstitutional status prevents disorder in case all members of the Diet lose their eligibility by judicial decision. The doctrine urges the Diet to reform the allocation of the number of members in the constituency, without stipulating a specific period of time in which to do so. A message of caution from the Japanese Supreme Court might not be heeded by the Diet, as it is a dysfunctional branch of government.

In Japan, constituency reform is overseen by members of the parliament. An electoral district-fixing council is established in the parliament after judicial decisions, and the majority of the ruling party may modify its council advice. An electoral system with the single-seat constituency system of the House of Representatives was introduced by the Diet in 1994. This system is advantageous to sitting members of the ruling party. The elimination of seats in its electoral district by reform means that members of the Diet lose the support of groups in their district.

A parliamentary system of government was adopted into the Japanese Constitution in 1947, which was strongly influenced by the Allied Powers. Although the 
Constitution does not state that the prime minister can dissolve the House of Representatives, this occurred in a landmark precedent, the Tomabechi case in 1960. Constitutional scholars argue that in some cases, the House of Representatives was dissolved without solving pertinent political issues for the Japanese people. The Tomabechi case requires further research by Japanese Constitutional law scholars.

The Japanese Supreme Court might have adopted a different judicial review system in cases of election of the Diet. Japanese judicial review requires disputes on matters of law to be brought to court. The Public Officer Election Act provides exceptions that allow voters to argue that an election is null and void. Recently, some lower courts have changed their approach to voting on value disparity cases, and have held these cases to be unconstitutional without using the unconstitutional state doctrine. The Supreme Court might change in the future as a result of discussions among Japanese constitutional law scholars.

The purpose of this paper is to initiate domestic discussion among Japanese constitutional law scholars regarding vote value disparity and judicial review in Japan.

\section{THE CONSTITUTIONAL DRAFTING PERIOD AND ORGANIZA- TION OF THE CURRENT DIET}

\subsection{The amendment of the Meiji Constitution}

The Japanese Constitution was amended from the Meiji Constitution, the Constitution of the Empire of Japan. Accepting the Potsdam Declaration issued on July 26, 1945, or the Proclamation Defining Terms for Japanese Surrender, the Meiji government surrendered and was subjected to the will of the General Headquarters (GHQ). The General of the United States army, MacArthur Douglas, was the Supreme Commander for the Allied Powers.

MacArthur ordered the Joji Matsumoto Committee to draft the new Constitution. On February 1, 1945, the Mainichi newspaper published its draft, which surprised MacArthur, as it still remained a conventional constitution with only minor changes. 
MacArthur thus ordered the drafting of a new constitution with three principles $^{1}$ and established a task force on February 3, 1946. ${ }^{2}$ The GHQ submitted the draft of the new constitution. Just before February 8,1946 , the Matsumoto Committee submitted his draft to the $\mathrm{GHQ}$, called the Tentative Revision of the Constitution, with his supplementary explanations. ${ }^{3}$

Matsumoto prepared two types of drafts. The submitted draft provided that the Emperor was the head of the state, and could dissolve the House of Representatives. The Emperor was prohibited from dissolving the House of Representatives twice on the same grounds. Furthermore, the draft proposed two houses for the Diet.

The Matsumoto Committee draft was rejected on February 13, 1945, and the GHQ showed its draft to the Japanese government. The Japanese government and the GHQ worked together to amend the draft from February 27 to April 17 as the Draft for a Revised Constitution.

MacArthur's draft on February 12 provided that the Emperor was a symbol of the Japanese people, and "[T] he Diet shall consist of one house of elected representatives with a membership of not less than 300 , nor more than $500 .^{\prime 4}$

The current Japanese Constitution outlines two houses in its parliament, or the Diet, as it's called in Japan: the House of Representatives and the House of Councillors. ${ }^{5}$ The main result of MacArthur's draft was the abolishment of the Emperor's sovereign-

\footnotetext{
TSUJ, Yuichiro. Article 9 and the History of Japan's Judiciary: Examining Its Likeness to American and German Courts. Tsukuba Journal of Law and Politics, Tsukuba, vol. 68, p. 35-78, oct. 2016. The origin and history of the Japanese Constitution in English. Birth of the Constitution of Japan [English]. < http://www.ndl.go.jp/ constitution/e/index.html >. (last visited on February 26, 2016). HALEY, John. The Spirit Of Japanese Law. Athens: University of Georgia Press, 2006. RAMSEYER, Mark; RASMUSEN, Eric. Measuring Judicial Independence: the political economy of judging in Japan. Chicago: University of Chicago Press, 2003. p. 21. Ramseyer showed LDP control over the General Secretary of the Supreme Court in malapportionment cases before judicial reform in 1990s. TANAKA, Hideo. A History of the Constitution of Japan of 1946. In: TANAKA, Hideo; SMITH, Malcolm (Eds.). The Japanese Legal System. Tokyo: University of Tokyo Press, 1976. p. 653. BEER, Lawrence. Peace in Theory and Practice under Article 9 of Japan's Constitution. Marquette Law Review, Milwaukee, vol. 81, n. 3, p. 815-830, mar./may1998.

2 I. The Emperor is the head of the State and his succession is dynastic. His duties and powers will be exercised in accordance with the constitution and he is responsible to the basic will of the people as provided therein.

II. War as a sovereign right of the nation is abolished. Japan renounces it as an instrumentality for settling its disputes and even for preserving its own security. It relies upon the higher ideals that are now stirring the world for its defense and its protection. No Japanese army, navy, or air force will ever be authorized and no right to the belligerence will ever be conferred upon any Japanese force. III. The feudal system of Japan will cease. No rights of peerage except those of the Imperial Family will extend beyond the limits of those now existent. No patent of nobility will from this time forth embody within itself any national or civic power of government. The budget will be modeled after the British system.

3 Prof. Toshiyoshi Miyazawa at Tokyo University helped Matsumoto with the constitutional draft.

4 TSUJ, Yuichiro. Article 9 and the History of Japan's Judiciary: Examining Its Likeness to American and German Courts. Tsukuba Journal of Law and Politics, Tsukuba, vol. 68, p. 35-78, oct. 2016.

5 NIHONKOKU KENPO [KENPO][CONSTITUTION], Art.42. The Diet shall consist of two Houses, namely the House of Representatives and the House of Councillors.
} 
ty and the House of Peers. The Japanese government proposed the idea of a bicameral legislature. However, the GHQ objected to two houses since Japan did not have a federal system, stating "disputes would arise over the weight of authority between the two houses." ${ }^{\prime \prime}$ Nevertheless, the Japanese persuaded the GHQ, and two houses were established in the Draft for a Revised Constitution (March 6 draft) in 1946. The House of Councillors was created to mitigate the decision-making power of the lower house. However, clear divisions and differences between the House of Councillors and the lower house were not clearly stipulated in the Japanese Constitution. ${ }^{7}$

\subsection{General elections under the Meiji Constitution and the current Diet}

Voting rights were granted to men in 1925 under the Meiji Constitution; women's suffrage was provided by the revised House of Representatives Election Law and a general election was held on April 10, 1946. Imperial parliament under the Meiji Constitution was opened on May 16, 1946. Thus, this election had implications for the drafting of the new Japanese Constitution.

The Imperial Parliament deliberated the draft of the Japanese Constitution. It passed the House of Representatives and the House of Peers. During this plenary session, a small committee made several modifications. This Constitution adopted the three principles suggested by MacArthur. The Japanese Constitution was promulgated on November 3, 1946, and came into force on May 3, 1947.

The Japanese government submitted two drafts on March 2 and March 5 in 1946 , both of which named the Emperor as the symbol of the nation, and proposed two Houses in the Diet. ${ }^{8}$

\footnotetext{
6 TSUJ, Yuichiro. Article 9 and the History of Japan's Judiciary: Examining Its Likeness to American and German Courts. Tsukuba Journal of Law and Politics, Tsukuba, vol. 68, p. 35-78, oct. 2016. See also, The origin and history of the Japanese Constitution. Birth of the Constitution of Japan [English]. <http://www.ndl.go.jp/constitution/e/index.html>. (Last visited on 26 March, 2016). "Milo E. Rowell, Judicial Affairs Officer in Government Section, GHQ, indicated in "Report of preliminary studies and recommendations of the Japanese Constitution." The comment of [Report of preliminary studies and recommendations of the Japanese Constitution] that either a unicameral or bicameral legislature would be acceptable, as long as all the legislators were elected. On top of that, the U.S. Government also recommended that the legislative body be fully representative of the electorate in Reform of the Japanese Governmental System (SWNCC 228). The comment of [Reform of the Japanese Governmental System (SWNCC 228) comment], sent to MacArthur for his "information."

7 KATO, Kazuhiko. Sangi-in no Isikika sareta Genzo Keisei. Tokyo Keizai Law Review, Tokyo, vol. 30, p. 199-?, 2016.

8 Some private drafts written for the Japanese Constitution suggested a presidential system and the abolishment of the Emperor, such as that written by the leader of the Constitution Investigation Association, Iwasaburo Takano. Takano wrote his own draft of the Constitution in which he proposed a presidential system with two Houses in the Diet and the elimination of the Emperor system. At that time, the abolishment of Emperor was a very sensitive issue.
} 
Article 43(2) of the Japanese Constitution states "[B]oth Houses shall consist of elected members, representative of all the people. The number of the members of each House shall be fixed by law." The number of both Houses was established in the Public Officer Election Act [Koushoku Senkyo Hou]. Article 4 of the Public Officer Election Act ${ }^{9}$ stated that the total number of seats in the House of Representatives was 475, and that of the House of Councillors was 242. ${ }^{10}$

Article 45 of the Japanese Constitution ${ }^{11}$ states that the term of office for the House of Representatives is 4 years, and 6 years for the House of Councillors. Article $46^{12}$ of the Japanese Constitution stipulates that an election for half the members shall take place once every three years. The Public Officer Election Act was amended in 2015, and the suffrage age was changed to 18 years old beginning from the July, 2016 election for the House of Councillors. ${ }^{13}$ Article 10 of the Public Officer Election Act provides that a person of 25 years of age or older may run as a candidate to become a member of the House of Representatives, and 30 years of age or older for the House of Councillors. ${ }^{14}$ The reason for a 5-year difference between the two Houses is not clearly stated in the Japanese Constitution, nor is the unique function of the House of Councillors.

\section{ELECTORAL SYSTEM}

\subsection{The Tomabechi case and the House of Representatives}

The House of Representatives adopted an electoral system comprised of single-seat constituencies and proportionally represented, multiple-seat constituencies (Shou Senkyoku Hirei Daihyou Heiritsu). ${ }^{15}$ A total of 290 members were selected from single-seat constituencies as of $2016 .{ }^{16}$ The voter states one candidate's name on the ballot paper at the polling place for a single-seat constituency (Shou Senkyoku). The remaining 180 members are selected from proportionally represented, multiple-seat constituencies (Hireidaihyou). ${ }^{17}$ Japan is divided into 11 districts, and voters state the

Koshoku Senkyo Hou [Japanese Public Officer Election Act], Law No. 60 of 2015, Art.4. (Japan).

10 See id. Art. 4.

11 NIHONKOKU KENPO [KENPO][CONSTITUTION], Art.45. The term of office of members of the House of Representatives shall be four years. However, the term shall be terminated before the full term is up in case the House of Representatives is dissolved.

12 Id. Art. 46. The term of office of members of the House of Councillors shall be six years, and election for half the members shall take place every three years.

13 Koshoku Senkyo Hou [Japanese Public Officer Election Act], Law No. 60 of 2015, Art.9 (Japan).

14 See id. Art. 10.

15 Id. Art. 12.

16 Id. Art. 12, 13, Appendix 2.

17 Id. Art. 13 (2), Appendix 2. 
name of a political party on the ballot paper. The list is submitted by the political party beforehand, and this decides the elected representatives from the top name of the list (Kousoku).

In the allocation of parliamentary seats in a proportional representation system, the d'Hondt formula was used. ${ }^{18}$

The House of Representatives may be dissolved by a non-confidence resolution against the cabinet under Article $69^{19}$ of the Japanese Constitution. The Japanese Constitution has a parliamentary system. Although the core of the parliamentary system is not clear, ${ }^{20}$ the cabinet and legislature are expected to work together. ${ }^{21}$ The cabinet stands on the confidence of the legislature. Article 69 of the Constitution stipulates that the House of Representatives must pass a non-confidence resolution, or reject a confidence resolution; the Cabinet shall resign en masse, unless the House of Representatives is dissolved within 10 days. In the case of dissolution, all members of the House of Representatives lose their office and must run for the next general election.

Impliedly, Article $7^{22}$ of the Japanese Constitution has been used by the cabinet to dissolve the House of Representatives. Chapter I of the Japanese Constitution outlines the role of the Emperor. Under the Japanese Constitution, sovereignty belongs to the people of Japan, not the Emperor. The Emperor's role is ritual and formal without any political authority. Each paragraph of Article 7 provides that the Emperor acts in matters of the state on behalf of the people. These acts shall be performed with the advice and approval of the cabinet. ${ }^{23}$

Paragraph 3 of Article 7 of the Constitution deals with the dissolution of the House of Representatives. The cabinet has used this Article to dissolve the House of Representatives even in cases without a non-confidence resolution. Under the Japanese parliamentary system, the prime minister is also usually the head of the political party that has the majority of seats in the Diet. ${ }^{24}$ The Japanese prime minister is selected from

\footnotetext{
18 Koshoku Senkyo Hou [Japanese Public Officer Election Act], Law No. 60 of 2015, Art. 95(2) (Japan).

19 NIHONKOKU KENPO [KENPO][CONSTITUTION], Art.69. If the House of Representatives passes a non-confidence resolution, or rejects a confidence resolution, the Cabinet shall resign en masse, unless the House of Representatives is dissolved within 10 days.

20 One position understands that in the parliamentary system, the cabinet and the parliament oppose each other equally. The other position understands that the cabinet stands on the trust of the parliament, and both work together. This difference in positions on the parliamentary system would lead the cabinet's power to dissolve the House of Representatives.

Kazuiki Takahashi, Kokumin Naikaku sei Sairon [Nation Cabinet again, vol.2] 1137 Jurist 93-95 (1998).

21 SATO, Koji. Kenpo [Constitution]. Tokyo: Seibundo, 2011. p. 476.

22 NIHONKOKU KENPO[KENPO][CONSTITUTION], Art.7(3). The Emperor, with the advice and approval of the Cabinet, shall perform the following act in matters of state on behalf of the people: dissolution of the House of Representatives.

23 Id.

24 In Japanese political history, the prime minister was selected from the coalition parties. In this case, the prime minister was not head of the party that occupied the majority in the House of Representatives.
} 
the members of each House of the Diet, according to Article $67^{25}$ of the Constitution. However, according to convention, the prime minister has usually been selected from the House of Representatives, not the Councillors, as the House of Representatives is more popular among voters, as it can be dissolved and the term of office is shorter. ${ }^{26}$

Interpretation of Article 7 on dissolution is based on the well-known Tomabechi case. The third Shigeru Yoshida cabinet dissolved the House of Representatives using Article 7 in August, 1952. Concluding the San Francisco Treaty ${ }^{27}$ in 1951, the occupation of the GHQ was completed. Those who were exiled from public offices by the GHQ returned to the government. One of those exiled was Ichiro Hatoyama, a political rival of Yoshida in the Liberal Party, ${ }^{28}$ who demanded the resignation of Shigeru Yoshida's cabinet. ${ }^{29}$ Yoshida dissolved the Cabinet on August 28, 1952; this decision was secretly decided by a small group, who aimed to prepare for the election in order to oppose Hatoyama. This is called a surprising unannounced dissolution (Nukiuchi Kaisan).

Gizo Tomabechi, a member of the House of Representatives and of the National Democratic Party, lost seats in this election. ${ }^{30} \mathrm{He}$ took legal action arguing that the dissolution based on Article 7 was null and void without Article 69. The Supreme Court ${ }^{31}$ denied Tomabechi's appeal. ${ }^{32}$ It held that its dissolution was too political and outside the jurisdiction of the judiciary. This is called a political question theory in Japan (Touchi Koui ). The three opinions explained that the judiciary could review the dissolution, and in 1952, the dissolution became legal and effective.

Justice Katsushige Kotani, joined by Kenichi Okuno, believed that the dissolution was under judicial review. Dissolution by Article 7 was a political action that was transformed by cabinet advice and approval into ritual conduct of the Emperor. The district court approved the advice and approval of the cabinet; thus, the dissolution was constitutionally effective.

25 NIHONKOKU KENPO[KENPO][CONSTITUTION], Art.67. The prime minister shall be designated from among the members of the Diet by a resolution of the Diet. This designation shall precede all other business.

26 NONAKA, Toshihiko; NAKAMURA, Mutsuo; TAKAHASHI, Kazuyuki; TAKAMI, Katsutoshi. Kenpo II [Constitution II]. Tokyo: Yuhikaku, 2012. p. 180.

27 Treaty of Peace with Japan (Sept. 8, 1951).

28 The Liberal Democratic Party in Japan was formed in 1955.

29 Yoshida and Hatoyama promised that Yoshida would hand over leadership of the Liberal Party to Hatoyama in 1946 when he was purged by the GHQ.

30 Tomabechi was a member of the group that went to sign the San Francisco Treaty in 1951. It took effect in 1952. Article 7 dissolution was

31 Saiko Saibansho [Sup. Ct] June 8, 1960, Showa 30(0) no.96, 14(7) Saiko Saibansho Minji Hanreishu [Minshu] 1206 (Japan).

32 The Tokyo district court held that dissolution without advice and consent of the cabinet was unconstitutionally null and void. Tokyo Chiho Saibansho [Tokyo Dist.Ct.] October 19, 1953, Showa 27 (Gyou) no. 156, 14(7) Saiko Saibansho Minji Hanreishu [Minshu] 1251 (Japan). The Tokyo high court held that the cabinet advised the dissolution, which was constitutional. Tokyo Koto Saibansho [Tokyo High Ct.] September 22, 1954, Showa 28 (ne) no. 2010. 14(7) Saiko Saibansho Minji Hanreishu [Minshu] 1265 (Japan). 
Justice Daisuke Kawamura noted that an intrinsic limitation of the judiciary theory was against Article $81^{33}$ of the Constitution. The judiciary's mission is to protect people's rights, and should not refrain from judicial review in the name of abstaining or for overly political concerns. In this case, Article 7 granted the cabinet the power to dissolve the House of Representatives. The advice and approval provided in Article 7 is indistinguishable. In this case, the advice and approval was legal and effective.

Justice Shuichi Ishida noted two issues in this case. One was that the cabinet could dissolve the Diet, which was outside of the judiciary's jurisdiction. The other was the advice and approval of the cabinet, which was under judicial review.

There are several differences between the cases of Tomabechi and Sunagawa, ${ }^{34}$ the latter of which occurred 6 months before Tomabechi. Sunagawa used the political question theory for the defense and security treaty ${ }^{35}$ concluded between Japan and the United States in September 1951. ${ }^{36}$

First, the Tomabechi case's justification for the Article 7 dissolution relied on legislative discretion. Second, the words "clearly obvious unconstitutionality or invalidity" in Sunagawa were not used in Tomabechi. ${ }^{37}$ It is not clear what factors were used to determine something to be an example of "clearly obvious unconstitutionality or invalidity". Thus, the political question theory might not be required in Tomabechi, for the judiciary to review the dissolution by the cabinet.

Second, the political question doctrine in the Tomabechi case was doubtful. The Supreme Court could have used the autonomy and discretion of the cabinet decision because the political question doctrine is not provided in text of the Japanese Constitution. It is based on the people's intrinsic sovereignty, but its scope should be clearly limited. ${ }^{38}$

\footnotetext{
33 NIHONKOKU KENPO [KENPO][CONSTITUTION], Art.81.The Supreme Court is the court of last resort with power to determine the constitutionality of any law, order, regulation, or official act.

34 Saiko Saibansho [Sup. Ct] Dec. 16, 1959, Showa 34(a) no.710, 13 Saiko Saibansho Keiji Hanreishu [Keishu] 3225.

35 Kyu Nihonkoku to Amerika Gasshukoku to no aidano anzen hoshou jouyaku [The old security treaty between Japan and the United States], Japan-U.S., 28 April 1952, Treaty no. 6, 1952.

36 TSUJ, Yuichiro. Constitutional Court in Japan. Tsukuba Journal of Law and Politics, Tsukuba, vol. 66, p. 65-87, mar. 2016. p. 84. See also, KAMATA, Taisuke. Adjudication and the Governing Process; Political Questions and Legislative Discretion. In: LUNEY, Percy; TAKAHASHI, Kazuyuki (Eds.). Japanese Constitutional Law. Tokyo: University of Tokyo Press 1993. p. 156-157.

37 NONAKA, Toshihiko; NAKAMURA, Mutsuo; TAKAHASHI, Kazuyuki; TAKAMI, Katsutoshi. Kenpo II [Constitution II]. Tokyo: Yuhikaku, 2012. p. 280. SATO, Koji. Kenpo [Constitution]. Tokyo: Seibundo, 2011. p. 641.

38 NONAKA, Toshihiko; NAKAMURA, Mutsuo; TAKAHASHI, Kazuyuki; TAKAMI, Katsutoshi. Kenpo II [Constitution II]. Tokyo: Yuhikaku, 2012. p. 18. ASHIBE, Nobuyoshi. Kenpo [Constitution]. 6. ed. Tokyo: Iwanami Shoten, 2015. This book is still being edited by Prof. Kazuyuki Takahashi after Prof. Ashibe passed away.
} 
Nobuyoshi Ashibe noted several conditions for dissolution by the cabinet. ${ }^{39}$ First, an important bill submitted by the cabinet is not passed in parliament, or the cabinet shelves the bill. Second, the fundamental nature of the cabinet is changed by political realignment. Third, there is a need to deal with new important issues that have not arisen in the general elections. Fourth, the cabinet changes its fundamental policy drastically. Fifth, the term of the members of the House of Representatives is nearly complete, in which case arbitrary dissolution is prohibited. ${ }^{40}$

Koji Sato believes that acts based on Article 7 are political, which are transformed into ritual through cabinet decision. He agreed with Ashibe that arbitrary dissolution by the cabinet should be limited, and the question of whether dissolution based on Article 7 is justified depends on the cabinet decision. ${ }^{41}$ Both agree that the constituent body should review its dissolution by voting under the name of the people's sovereignty.

\subsection{Reform of the House of Representatives}

In 1984, the elections to the House of Representatives used to be based on an electoral district system called a "medium" electoral district system (Chu Senkyo Ku), beginning in the Meiji Constitution period. The name "medium" was used in Japan, but it is the major constituency system that chooses three to five representatives in one constituency. The constituency was fixed by the size of the population and the geographical size in the Meiji Constitution period. The first general election in 1947 utilized the major constituency system, the medium electoral district system for the new Japanese Constitution.

The allocation of members was based on the population at that time. The Public Officer Election Act provided that the allocation would be looked over by the national census every 5 years. ${ }^{42}$ The allocation system was not overhauled; however, partial adjustments were made several times.

In 1994, the medium electoral district system was changed to an electoral system comprised of single-seat constituencies (Shou Senkyoku) and proportionally represented, multiple-seat constituencies (Hirei Daihyo). The election in 1996 introduced the current system. ${ }^{43}$

\footnotetext{
39 ASHIBE, Nobuyoshi. Kenpo [Constitution]. 6. ed. Tokyo: Iwanami Shoten, 2015. p. 335. Sato thinks it is problematic that the cabinet decision is beyond judicial review. SATO, Koji. Kenpo [Constitution]. Tokyo: Seibundo, 2011 p. 497.

40 TSUJ, Yuichiro. Amendment of the Japanese Constitution - A Comparative Law Approach. Nanzan Review of American Studies, Aichi, vol. 37, p. 51-70, 2015.

41 SATO, Koji. Kenpo [Constitution]. Tokyo: Seibundo, 2011 p. 452, 477, 503, 519.

42 Koshoku Senkyo Hou [Japanese Public Officer Election Act], Law No. 60 of 2015, Art. 203, 204 (Japan).

43 MATSUI, Shigenori. Kenpo [Constitution of Japan]. Tokyo: Yuhikaku, 2007.
} 
The Japanese Constitution has not provided clear details outlining the electoral districts and methods for election. Article $14^{44}$ of the Constitution provides equal protection under the law, and Article $44^{45}$ prohibits discrimination based on race, creed, sex, social status, family origin, education, property, or income in order to qualify as a member of both Houses and their electors. Japanese Constitutional scholars believe that the one vote per person principle and equality are requirements of the Constitution. ${ }^{46}$

The district-fixing council ${ }^{47}$ (Senkyo Kukaku Shingi linnkai) for the House of Representatives was established under the cabinet office. The seven members are chosen from among experts, and their job is to advise the prime minister. Based on this advice, the government may submit a bill to parliament to amend the Public Officer Election Act, based on Article $72^{48}$ of the Constitution.

The district-fixing council is not included in the Constitution, and its opinion is advisory with no binding power; that is to say that its advice does not bind the cabinet. The council's autonomy to fix the electoral districts might be constitutionally required if the judiciary declares that voting disparity has been unequal under unconstitutional conditions or states (Iken-Joutai)..$^{49}$ The Supreme Court may reflect the council's importance in writing its Iken-Jotai decisions.

The choice of this electoral system contains both advantages and disadvantages. In constitutional law studies in Japan, this issue is reviewed in terms of the relationship between voters and representatives. This issue is reviewed in Chapter III.

44 NIHONKOKU KENPO [KENPO][CONSTITUTION], Art.14. All of the people are equal under the law and there shall be no discrimination in political, economic, or social relations because of race, creed, sex, social status, or family origin.

45 See id. Art. 44. The qualifications of members of both Houses and their electors shall be fixed by law. However, there shall be no discrimination because of race, creed, sex, social status, family origin, education, property, or income.

46 NONAKA, Toshihiko; NAKAMURA, Mutsuo; TAKAHASHI, Kazuyuki; TAKAMI, Katsutoshi. Kenpo II [Constitution II]. Tokyo: Yuhikaku, 2012. p. 18-. See also, ASHIBE, Nobuyoshi. Kenpo [Constitution]. 6. ed. Tokyo: Iwanami Shoten, 2015. p. 42.

47 Shugin Giin Senkyoku Kakutei Shingikai Sechi Hou [The Act for electoral district-fixing committee for the House of Representatives], Law No. 95 of 2012 (Japan).

48 NIHONKOKU KENPO [KENPO][CONSTITUTION], Art.72. The Prime Minister, representing the Cabinet, submits bills, reports on general national affairs and foreign relations to the Diet, and exercises control and supervision over various administrative branches.

49 TOMATSU, Hidenori. Equal Protection of the Law. In: LUNEY, Percy; TAKAHASHI, Kazuyuki (Eds.). Japanese Constitutional Law. Tokyo: University of Tokyo Press, 1993. p. 195. Tomatsu translated Iken Joutai to circumstances decision. HALEY, John. The Spirit Of Japanese Law. Athens: University of Georgia Press, 2006. p. 182. John Haley argues that " the Japanese judiciary may seem in these cases weak and impotent". 


\subsection{The purpose of the House of Councilors}

The bicameral system in Japan means that the two Houses of the Diet manage their business independently and equally. During the drafting of the Japanese Constitution, the Japanese government explained to the GHQ that an upper House would prevent arbitrary parliamentary decision-making by the lower House, and "a change in government to a unicameral system might pose the threat of radical shifts in government policy, and a bicameral system would promote stability and continuity in government policies." ${ }^{50}$ Japanese Constitutional law scholars explain further that the House of Councillors prevents hasty decision-making by the House of Representatives, and mitigates collision between the House of Representatives and the cabinet. By using two different voting systems in two Houses, various opinions are reflected in parliament. However, as the power of political party was strong, the House of Councillors has been criticized as being a copy of the House of Representatives, with no unique function.

When the two Houses collided in four cases, the decision of the House of Representatives was deemed superior to that of the House of Councillors, in matters related to bills, treaties, budgeting, and the nomination of the prime minister. The purpose of these specific conditions in the Japanese Constitution is to promote the decision -making power of the Diet. In addition, the House of Representatives is closer to the voters, and a stable and strong cabinet is maintained.

The House of Councillors does not have a "general" election, in that only half of the members are selected every 3 years. Thus, 121 councilors are selected every 3 years. Out of 242 members, 96 members are selected through proportional representation, which covers all territories in Japan. On ballot papers, voters state the name of the candidate, or the name of the political party. The election system, called the Electoral District System (Senkyoku-Senkyo), selects the remaining 146 members (73 seats every 3 years) of the House of Councillors. Unlike the proportionally representative election of the House of Representatives, the fixed list of candidate names is not prepared by the political party. It is called Hi-Kousoku Meibo in Japanese. In the proportionally representative election (Hirei Daihyo), ${ }^{51} 96$ seats (48 seats every 3 years) are given, and voters can choose to write the name of the candidate or the political party. Two routes are used to decide the chosen representatives.

First, the political party obtains votes with the name of the party and the name of party's candidate. Then, the number of the seats the party acquires is fixed.

50 HALEY, John. The Spirit Of Japanese Law. Athens: University of Georgia Press, 2006 TSUJI, Yuichiro. Article 9 and the History of Japan's Judiciary: Examining Its Likeness to American and German Courts. Tsukuba Journal of Law and Politics, Tsukuba, vol. 68, p. 35-78, oct. 2016.

${ }^{51}$ Koshoku Senkyo Hou [Japanese Public Officer Election Act], Law No. 60 of 2015, Art.12 (Japan). 
Second, the ballot papers received by each candidate are counted. The candidate name list is then prepared and ordered according to those who obtain the most votes. It is not prepared beforehand. The allocation follows the d'Hondt formula. ${ }^{52}$

It has been controversial whether the House of Councillors is regionally representative. The drafting history of the Japanese Constitution does not show clear evidence of efforts to have Japanese regional differences reflected in the House of Councillors.

Koji Sato is concerned ${ }^{53}$ about the extensive influence of the House of Councillors in parliament; the Houses of the Diet are controlled by opposing parties (Nejire Kokkai ). In the Japanese parliamentary system, the prime minister is selected from the House of Representatives after dissolution. When the majority of the members of the House of Councillors are from opposite parties, the prime minister must uphold public commitments. He emphasizes effective management of the Conference Committee of both Houses (Ryouin Kyougi Kai). ${ }^{54}$

Sato explains that the core of the parliamentary system varies from time to time and country to country, and the constituent body shall be centralized in the Japanese parliamentary system; the parliament and cabinet seek support from the constituent body under the people's sovereignty. ${ }^{55}$

Kazuyuki Takahashi explains that the single constituency system expects two large political parties in the Diet; the Diet and the cabinet are equally in conflict with each other, as the parliamentary motion of non-confidence against the cabinet and the dissolution of the House of Representatives by the cabinet leave no reservation. In addition, parliament and the cabinet engage the will of the voters. Both parliament and the cabinet have the "weapons" to destroy each other in general elections. In the worst scenario, both reflect the voters' will. ${ }^{56}$

Toshiyuki Munesue explains two characteristics of the Japanese parliamentary system. One is that the House of Representatives is in equal conflict with the cabinet as an Article 7 dissolution asks for the voter's judgment in general elections; and the House of Representatives review "conducts affairs of state" and shape higher policies

\footnotetext{
52 Koshoku Senkyo Hou [Japanese Public Officer Election Act], Law No. 60 of 2015, Art. 86(3) (Japan).

53 SATO, Koji. Kenpo [Constitution]. Tokyo: Seibundo, 2011. p. 439-444.

54 Kokkai Hou [The Diet Act] Law No. 86 of 2014, Art 83(2)- (Japan).

55 SATO, Koji. Kenpo [Constitution]. Tokyo: Seibundo, 2011. p. 439.475-479.
}

56 TAKAHASHI, Kazyuki. Rikkenshugi To Nihonkokukenpo [Constitutionalism and the Constitution of Japan] Tokyo: Yuhikaku, 2013.; TAKAHASHI, Kazuyuki. Contemporary Democracy in a Parliamentary System. In: LUNEY, Percy; TAKAHASHI, Kazuyuki (Eds.). Japanese Constitutional Law. Tokyo: University of Tokyo Press, 1993. He focuses on party behavior in parliamentary system. NONAKA, Toshihiko; NAKAMURA, Mutsuo; TAKAHASHI, Kazuyuki; TAKAMI, Katsutoshi. Kenpo II [Constitution II]. Tokyo: Yuhikaku, 2012.

TAKAHASH' Kazyuki. Rikkenshugi To Nihonkokukenpo [Constitutionalism and the Constitution of Japan] Tokyo: Yuhikaku, 2013. p. 172-173. 
by the cabinet in Article 73(1). ${ }^{57}$ Second, the House of Councillors should seek cabinet accountability for the "faithful administration of law" in Article 73(1), and cooperate and work together with the cabinet. ${ }^{58}$

\subsection{Reform of the House of Councillors}

The current electoral system was adopted in 1982 and 1994 by the amended Political Officer Election Act. From 1947 to 1982, the election for the House of Councillors has utilized a national constituency electoral system (Zenkoku $\mathrm{Ku}$ ) in all territories of Japan as one electoral zone for 100 members. Its purpose was once explained in 1947 that occupational ability must be reflected. ${ }^{59}$

Japanese Constitutional scholars explain that a candidate can become a representative of the territories of Japan ${ }^{60}$ once he or she has been chosen under Article 43 of the Japanese Constitution. Campaign spending by candidates for the House of Councillors under the system of Zenkoku Ku was excessive and criticized. ${ }^{61}$

The Constitutional Research Committee (Kenpo Chousa Kai), established in 1956, argued that the two Houses of the Diet should be maintained and the character and organization of the House of Councillors was discussed. Since 1946, private committees have submitted advisory opinions to the cabinet.

Originally, the members of the House of Councillors were expected to be specialists such as university professors or vocational representatives. The House of Councillors used to be the House of Lords under the Meiji Constitution. Under the new Japanese Constitution, labor unions, religious organizations, and interest groups could send candidates with huge financial backing, and celebrities had an advantage even though their representatives were sparse and living remotely. Regional and vocational representatives in the House of Councillors are now decreasing due to political party domination.

In this election, 50 members were selected to be representatives. This system adopted the single, non-transferable vote in which voters could write only the name of a single candidate. Extra votes were wasted.

57 NIHONKOKU KENPO [KENPO][CONSTITUTION], Art.73(1). Article 73. The Cabinet, in addition to other general administrative functions, shall perform the following functions: administer the law faithfully; conduct affairs of state.

58 Toshiyuki Munesue, Niin Sei no Igi narabini Sangiin no dokujisei [Meaning of bicameral system and uniqueness of the House of Councillors], Reference 1- 19 (2015 April).

59 In drafting history, Tetsu Katayama, leader of the Japanese Socialist Party, which drafted its own Japanese Constitution, noted the House of Councillors aims to reflect occupations.

60 NIHONKOKU KENPO [KENPO][CONSTITUTION], Art.43. Both Houses shall consist of elected members, representative of all the people.

61 NONAKA, Toshihiko; NAKAMURA, Mutsuo; TAKAHASHI, Kazuyuki; TAKAMI, Katsutoshi. Kenpo II [Constitution II]. Tokyo: Yuhikaku, 2012. 
From 1983 to 1988, the House of Councillors started using proportional representation with a fixed name list (Kousoku Siki Hirei Daihyo). This changed into a nonfixed list (Hi-Kousoku Meibo) beginning with the 2001 election. The number of seats was changed in 1994, 2000, 2006, and 2015 by amending the Public Officer Election Act. ${ }^{62}$

For the 2016 election of the House of Councillors, two seats in Shimane and two seats in Tottori were combined and reduced to just two seats for the single district of Shimane and Tottori prefectures. Two seats in Tokushima and two seats in Kochi were combined and reduced to just two seats as one district of Tokushima and Kochi prefectures. Hokkaido, Tokyo, Aichi, Hyogo, and Fukuoka prefectures increased by two seats each. Miyagi, Niigata, and Nagano prefectures decreased by two seats each. Two seats were also removed from Niigata, Miyagi, and Nagano prefectures. ${ }^{63}$

The Conference of Reforming the House of Councillors (Sangiin Kaikaku Kyogikai) has discussed reform of the electoral system since 2005. One of several proposals advocated reform of the Electoral District System (Senkyoku-Senkyo) in 2005. Its purpose was to prevent voting disparity four times. The Diet did not agree, and accepted an alternative proposal, which advocates four plus four minus seats.

\section{MAJOR DECISIONS AND JUDICIAL REVIEW}

\subsection{Japanese judicial review and elections}

The Japanese Constitution has one chapter related to the judiciary, and clearly provides judicial review in Article $81^{64}$ of the Constitution. Japanese judicial review is a substantive judicial review, which is exercised in all legal disputes, not an abstract review without disputes in matters of law. The requirement is provided in Article 3 of the Court Act. ${ }^{65}$ A plaintiff needs to prove the injury was in fact caused by the defendant, and is saved by the remedy of the court. This is called subjective litigation (Shukan Soshou). ${ }^{66}$ The validity of an election is not within the jurisdiction of subjective litigation because generalized grievances do not provide standing at the court.

The Japanese Constitution allows some exceptional litigation called objective litigation (Kyakkan Soshou) that does not require standing.$^{67}$ The purpose of objective

\footnotetext{
62 Koshoku Senkyo Hou [Japanese Public Officer Election Act], Law No. 60 of 2015, Art.4 (Japan).

63 Id. Art. 5-3 to 6.

64 NIHONKOKU KENPO[KENPO][CONSTITUTION], Art.81.

65 Saibansho hou [The Court Act], Law No. 48 of 2013. (Japan), Art.3(1). Courts shall, except as specifically provided for in the Constitution of Japan, decide all legal disputes, and have such other powers as are specifically provided for by law.

66 Gyousei Jiken Soshou Hou [Administrative Case Litigation Act], Law No. 59 of 2015, Art. 8, 9, 39 (Japan).

$67 \quad$ Id. Art. 42.
} 
litigation is to prevent illegal activity of the administrative agency and ensure that the administrative agency conforms to the law. ${ }^{68}$ In Japan, people's litigation (Minshu Soshou, citizen action) ${ }^{69}$ and litigation between agencies by statutes (Kikan Soshou, interagency action) fall under Article 5 and 6 of the Administrative Case Litigation Act, Gyousei Jiken Soshou Hou. ${ }^{70}$ The people's litigation includes residential litigation (Jumin Soshou $)^{71}$ and electoral litigation (Senkyo Soshou). ${ }^{72}$

The Public Officer Election Act allows voters to bring suit over the validity of the election. A voter may bring suit to contest the validity of the election, which is provided in the Public Officer Election Act.

The purpose of this litigation is for the judiciary to intervene and correct the dysfunctional channel between the Diet and the people, and to protect voting rights under Articles 14 and 44 of the Japanese Constitution. The election sends the voter's message to the Diet. ${ }^{73}$ The Supreme Court has held as unconstitutional the allocation of the number of members in the two Houses of the Diet several times.

\subsection{The 2009, 2012, and 2014 decisions for the House of Councillors}

In the 2009 decision ${ }^{74}$ concerning the election of 2007 in relation to disparity in the House of Councillors, however, the Supreme Court accepted a 4.86 disparity.

In 2014, the Supreme Court held ${ }^{75}$ that the election for the House of Councillors in July 2013 was unconstitutional (Iken-Jotai). In the July 2013 election, the disparity was 4.77 times between Hokkaido and Shimane prefectures in the Electoral District System (Senkyoku-Senkyo). The 2014 Supreme Court held that it was a remarkably unequal condition.

68 NONAKA, Toshihiko; NAKAMURA, Mutsuo; TAKAHASHI, Kazuyuki; TAKAMI, Katsutoshi. Kenpo II [Constitution II]. Tokyo: Yuhikaku, 2012. p. 276, 296. NONAKA, Toshihiko; NAKAMURA, Mutsuo; TAKAHASHI, Kazuyuki; TAKAMI, Katsutoshi. Kenpo II [Constitution II]. Tokyo: Yuhikaku, 2012; SATO, Koji. Kenpo [Constitution]. Tokyo: Seibundo, 2011. p. 585,587.

69 Gyousei Jiken Soshou Hou [Administrative Case Litigation Act], Law No. 59 of 2015, Art. 5 (Japan). The term 'citizen action' as used in this Act means an action seeking correction of an act conducted by an agency of the State or of a public entity which does not conform to laws, regulations, and rules, which is filed by a person based on his/her status as a voter or any other status that is irrelevant to his/her legal interest.

70 Id. Art. 5, 6.

71 Chihou Jichi hou [Local Autonomy Act], Law No.67 of 1947, Art.242-2.

72 Koshoku senkyo hou [Japanese Public Officer Election Act], Law No. 60 of 2015, Art.203, 204, 207, 211(Japan).

73 SATO, Koji. Kenpo [Constitution]. Tokyo: Seibundo, 2011. p. 339.

74 Saiko Saibansho [Sup.Ct.] Sep. 30, 2009, Heisei 20 (gyo tsu) 209, 63(7) Saiko Saibansho Minji Hanreishu [Minshu] 1520 (2009).

In this case, Justice Tokiyasu Fujita wrote concurring opinion which reasonable time limit should not be used for excuse for legislative inaction.

TOKIYASU FUJITA, SAIKOUSAI KAISOUROKU [Memory of the Supreme Court ] 301-306 (Yuhikaku 2012).

75 Saiko Saibansho [Sup.Ct.] Nov. 26, 2014, Heisei 26 (gyo tsu) 155, 68(9) Saiko Saibansho Minji Hanreishu [Minshu] 1363 (2014). 
In the 2014 decision, only nine months after the prior election and the Diet discussions on reforming of electoral districts, the Supreme Court avoided declaring the system unconstitutionally null and void. The 2014 decision warned that the electoral district system based on prefectures should be revised, and expected the Diet to implement immediate reform. The Supreme Court advised the Diet to consider integrating a revised plan for reform.

In 2012, the Supreme Court held as unconstitutional the electoral conditions of the House of Councillors in July 2010. The disparity was 5.0 times at the time of the election. The Supreme Court repeated Iken-Jotai twice in the two most recent elections for the House of Councillors, so that the 2012 and 2014 decisions encouraged reform of electoral system.

The text of the Japanese Constitution does not outline anything regarding the character of the House of Councillors in terms of the regional or prefectural representativeness of its members. The 2012 decision failed to properly represent regional prefectures, noting the population concentration in large cities and the large disparity in population was increasing; moreover, in an electoral district system based on regions or prefectures it is difficult to achieve voting equality.

Before the Diet revised the Public Officer Election Act, the Liberal Democratic Party (LDP) and the Democratic Party (Minshu) ${ }^{76}$, the largest opposing parties, insisted that the regional representative system in the House of Councillors should be maintained. The Komeito Party and Ishin Party argued that electoral districts based on prefectures should be abolished, and regional districts should be newly established. These discussions point to the advantage of the electoral strategy of larger political parties.

\subsection{The 2011, 2013, and 2015 decisions for the House of Representa- tives}

In March 2011, the Supreme Court held that the 2009 election of the House of Representatives was unconstitutional, using Iken-Jotai. In the 2009 election, the disparity was a maximum of 2.30 in the election of a single-seat constituency system. In 2009, the LDP lost seats in the election of the House of Representatives, and the Democratic Party came to power. The 2011 decision considered 17 months after the Public Officer Elections Act was revised, and the advisory committee reviewed the electoral system, using the Iken-Jotai doctrine.

The 2011 decision was declared in order to keep the system called "Hitori Betsuwaku Housiki," meaning one representative per prefecture regardless of its population.

76 The Democratic party was dissolved in 2016, and the Minshin Tou (The Democratic Party) was established. 
Since there are 300 single-seat constituencies in the House of Representatives, in this system, one representative is given to 47 prefectures, then 253 representatives are allocated as long as the disparity does not exceed 2.0 times. At that time, the total seats of the House of Representatives was 480.

The purpose of this system is to provide representatives to prefectures with small populations. This makes it more difficult for the legislature to dissolve disparity. For example, the population of Tottori prefecture is very small, but one seat was given. Tottori kept two seats by the Hitori Betsuwaku system.

In this 2011 decision, Justice Yuki Furuta noted the importance of regional opinion in the development of the country. Hitori Betsuwaku maintained reasonableness, and as compared with the precedent, the disparity in this case was still constitutional. According to Furuta, a reasonable time limit did not pass.

Justice Mutsuo Tabara wrote a dissenting opinion. He regarded Hitori Betsuwaku as unconstitutional because it did not reflect the voice and opinion of under populated areas. Even previous cases questioned the system; the legislature did not embark on reconsideration for revision of the electoral system, and a reasonable time limit had passed.

Justice Koji Miyagawa also wrote a dissenting opinion, and criticized Hitori Betsuwaku, which led to a disparity, and did not reflect the opinion of under populated regions. The decision should have been declared as an illegality of the election. If the Diet did not abolish it rapidly, the judiciary might declare future elections as unconstitutional.

After the 2011 decision, five seats of the House of Representatives were reduced by an amendment of the Public Officer Election Act from 480 to 475 . Five prefectures, Yamanashi, Fukui, Tokushima, Kochi, and Saga prefectures, were reduced by one seat to create single-seat constituencies.

In the meantime, in 2012 the House of Councillors removed four seats and added four others. Fukushima and Gifu prefectures lost two seats, while Osaka and Kanagawa prefectures received two seats. The total number of seats is still 242.

The district-fixing council submitted advice for this reform. ${ }^{77}$ Political compromise distorted its proposal. Originally, the council advised 21 reductions and 21 increases in the House of Representatives, but only a five-seat reduction plan was achieved. This reform did not take place in time for the December 2012 election of the House of Representatives, which Prime Minister Yoshihiko Noda dissolved by Article 7.

In November 2013, the Supreme Court announced as unconstitutional condition or situation in the election of 2012. Its disparity was 2.42. In December 2012, Prime

77 Shugiin Giin Senkyoku Kakutei Singikai Secchi Hou [The Act for Electoral District-Fixing Committee for the House of Representatives], Law No. 95 of 2012, Art.5 (Japan). When the council advises the prime minister, it shall report to the Diet. 
Minister Yoshihiko Noda dissolved the House of Representatives by Article 7 immediately following discussion with Shinzo Abe, the head of the LDP. Shinzo Abe and Yoshihiko Noda agreed to reform the electoral districts after the election in December 2012. This was the issue that the Abe administration faced in the 2016 Diet. The 2013 decision did not declare the election as unconstitutional, but noted a small reservation. The legislature is obligated to follow the Supreme Court declaration as an unconstitutional state or condition.

In the 2015 decision for the 2014 election of the House of Representatives, the disparity was 2.12 times. One of the high courts declared this as unconstitutionally illegal, ${ }^{78}$ and some high courts announced an unconstitutional state in March $2015 .^{79}$ The Supreme Court was asked to decide on a uniform decision for inferior courts.

In the 2015 decision, attorneys in favor of electoral reform argued that the majority decision under a distorted parliamentary electoral system is not the people's decision, and seats should be allocated by population exactly. The election management committee argued that designing an electoral system is under legislative discretion.

The 2015 decision avoided a clear unconstitutional announcement. Hitori Betsuwaku was abolished, and the five seats were reduced from 480 to 475 . Following the national census, disparity should be under two times. The 2015 Court explained that even though the Diet removed five seats, in thirteen electoral districts disparity is over two times. It was thus still an unconstitutional state. The Court noted that following the 2011 decision for election of the House of Representatives in 2009, the legislature made some efforts. Only 17 months after the amendment of the Public Officer Election Act for a five-seat reduction, the reasonable time limit did not pass for legislature to correct it.

The revised, 2016 Public Officer Election Act will reduce the number of members in the House of Representatives from 475 to 465 in 2017. This reform confronted strong objection from members chosen from under populated regions where conservative parties have traditionally been supported. Political parties are influential in ushering in reform by overcoming internal opposition. The next challenge will be who will be the official candidate in the electoral district endorsed by major political parties. Despite these reforms, Hitori Betsuwaku will remain in part. By Adam's method, electoral regions will get at least one seat no matter how small the population is, due to a function of rounding up digits after the decimal point to form an integer.

\footnotetext{
78 Hiroshima Koto Saibansho, Okayama branch [Hiroshima High Ct.] March 26, 2013, Heisei 24(Gyo ke) No.6, D1-Law.com no.28214274.

Nagoya Koto Saibansho, Kanazawa branch [Nagoya High Ct.] March 18, 2015, Heisei 24 (Gyo ke) No.1, D1-Law. com no. 28210933.

79 Fukuoka Koto Saibansho, Naha branch [Fukuoka High Ct.] March 26, 2015, Heisei 24(Gyo ke) No.1, D1-Law. com no. 28220585.

Tokyo Koto Saibansho [Tokyo High Ct.] March 6, 2015, Heisei 24 (wa) No.21, 2184 HANREI TAIMUZU [HANTA] 3.
} 


\section{THE REPRESENTATIVE AND THE VOTERS}

\subsection{The mission of the representative}

Under Article $43^{80}$ of the Japanese Constitution, members of the Diet are "the representatives of all the people," not simply the representatives of their own electoral zones. Constitutionalism requires that the ruler and the ruled must match, and deliberation of the Diet must reflect the voices of minorities who are far removed from politics. ${ }^{81}$

Under the Meiji Constitution, the relationship between the voter and the representative was considered to be similar to a legal agent of the Civil Code, under which the representative reflected the voices of people with mental disabilities. ${ }^{82}$ This opinion was criticized, as such people were regarded as defective or imperfect. During a democratic movement under the Meiji Constitution, called the Taisho democracy, some Constitutional scholars maintained that the purpose of the Imperial Parliament was to act as an agent of the people. The Supreme ruler was not the people, but the Emperor under the Meiji Constitution. The Meiji government banned some books and theories of Constitutional law scholars. ${ }^{83}$

Isao Sato explained that political representatives, following the notion provided by the 1791 French Constitution, were not legally bound by the voters. This idea reflected the ideas of the French Revolution, and is criticized as elitism. ${ }^{84}$

Nobuyoshi Ashibe ${ }^{85}$ modified Isao Sato's idea. We, the people, work through political representatives, not legally, and such institutions politically reflect the will of the people. The representative works to consolidate various people's opinions. The opinions of the ruler and the ruled, the people and the Diet, the voter and representative, collide in some cases.

Ashibe analyzed that in political representative systems, the people work through their representatives. The electoral body reflects the will of the people; the

\footnotetext{
80 NIHONKOKU KENPO[KENPO][CONSTITUTION], Art.43.

81 ASHIBE, Nobuyoshi. Kenpo [Constitution]. 6. ed. Tokyo: Iwanami Shoten, 2015. p. 42-43; $292-294$.

82 TATSUKICHI, Minobe. Kenpo Teiyou [Constitution]. 5. ed. Tokyo: Yuhikaku, 1932; SOUICHI, Sasaki. Nihon Kenpou Youron [The main theory of Constitution]. 3. ed. [s.I.]: Kanasashi Houryudou, 1933.

83 The most famous case was prohibition of a book written by professor Minobe Tatsukichi at Tokyo University in 1935 . He resigned a member of the House of Peers.

84 SATO, Isao. Pokeet Kenpo [Pocket Constitution]. vol. 1. Tokyo:Yuhikaku, 1983. p. 14-15; SATO, Isao. Pokeet Kenpo [Pocket Constitution]. vol. 2. Tokyo: Yuhikaku, 1984. p. 683; NONAKA, Toshihiko; NAKAMURA, Mutsuo; TAKAHASHI, Kazuyuki; TAKAMI, Katsutoshi. Kenpo II [Constitution II]. Tokyo: Yuhikaku, 2012. p. 56.

85 ASHIBE, Nobuyoshi. Kenpo to Gikaisei [Constitution and Parliamentary system]. Tokyo: Tokyo University Press, 1971

NONAKA, Toshihiko; NAKAMURA, Mutsuo; TAKAHASHI, Kazuyuki; TAKAMI, Katsutoshi. Kenpo II [Constitution II]. Tokyo: Yuhikaku, 2012
} 
representative pluralistically combines the wills of the people. The opinion between the people and the legislature, the voter and the representative, and the ruler and the ruled usually conflict. The political representative sees the political process as a dynamic communication between the voters and the electoral body. The political representative understands that his work is based on his own beliefs, which nevertheless sounds elitist. In some cases, the will of the voter and that of the representative might successfully match.

Sociological representatives are similar to political representatives in that a sociological representative is independent of the will of the voters and the collective will of society, and social forces balance to be reflected accurately in the legislature.

Semi-representatives developed in France imported by Japanese Constitutional researchers ${ }^{86}$ believe that it is better to reflect people's opinions in politics, which relates directly to democracy. It overlaps with sociological representation.

Influenced by French Constitutional studies, some Japanese Constitutional researchers understand the Japanese Constitution as a representation of "people power," as in the 1794 French Constitution. Some people approve the mandat imperatif, the modification of the privilege of exemption from liability, and demand a recall system for representatives in the Japanese Constitution.

\subsection{Political party control and discipline}

The term "political party" was not included in the Japanese Constitution. The political party was protected under freedom of association stipulated in Article 21 of the Constitution. According to a classification made by Professor Heinrich Triepel, Japanese Constitutional scholars explain that the Japanese Constitution takes the third stage, legalization and control by statute, not having yet reached the fourth stage of constitutionalization.

The political party receives subsidies under the Political Party Funding Law (Seito Josei $\mathrm{Hou}$ ). A political party comprising more than five members of the Diet is eligible to receive subsidies. Its resources are derived from taxes paid by the population based on the national census multiplying one politician by 250 yen. ${ }^{87}$ The subsidy is subject to the number of members in a political party. The power of the political parties is stronger than individual representatives in terms of political campaigns. Although not written in the Japanese Constitution, Japanese scholars explain that representatives make public

\footnotetext{
86 Ashibe, supra note 38, at p. 292-294; TSUJIMURA, Miyoko. Simin Shuken no Kanousei [Possibility of citizen sovereignty]. Tokyo: Yushindo, 2002. p. 175-176; TSUJIMURA, Miyoko. Note sur la theone du “mandat imperatif". [s.l.]: Hitotsubashi Kenkyu, 1977. Tsujimura develops people's sovereignty to citizen one. HIGUCHI, Youichi. Hikaku Kenpo [Comparative Constitution] 3. ed. [s.I.]: Seirin Shoin, 1992; TADANO, Masahito. The Right to vote and equality of value of vote. [s.I.]: Zenkoku Kenou Kenkyukai, 2015.

87 Seitou Josei Hou [Political Party Funding Law], Law No.69 of 2014, Art.7 (Japan).
} 
commitments to voters through political parties. Unlike the German Basic Law, ${ }^{88}$ which includes parties in its constitution, the conflict between representatives and parties does not occur so often except in the following case. ${ }^{89}$

A political party may require its members to adhere to party decisions. The representative selected through proportional representation is chosen under the name of their political party. The representative selected shall be the representative of the people under Article 43 of Japanese Constitution. ${ }^{90}$

The Diet Act and the Public Officer Election Act provide that the person selected by proportional representation in an election of the House of Representatives or Councillors, loses his or her seat when he or she changes the political party he or she belongs to. ${ }^{91}$ However, the members elected through the electoral district system do not lose seats. Japanese Constitutional scholars question this provision as the will of the representative is neglected. ${ }^{92}$

\section{IKEN-JOTAI DOCTRINE IN JAPAN}

The Japanese Supreme Court has repeatedly used the Iken-Jotai doctrine since the Constitution was established. This doctrine might include several uniform characters for Constitutional analysis outside Japan.

\subsection{The beginning of Iken-Jotai in a $\mathbf{1 9 7 6}$ decision}

In 1976, the Supreme Court held the allocation of the number of members in the House of Representatives as unconstitutional. ${ }^{93}$ This was the beginning of the IkenJotai doctrine.

Equality under the law, Article 14 (1), ${ }^{94}$ demands the equal value of votes. The allocation of members of the Houses of the Diet depends on the discretion of the legislature. As the Diet was beyond the reasonable judgment of equality, taking some circumstances into consideration, the Court held this as unconstitutional in 1976. In

\footnotetext{
88 Basic Law for the Federal Republic of Germany (Grundgesetz für die Bundesrepublik Deutschland), Art. 21(Artikel 21).

89 NONAKA, Toshihiko; NAKAMURA, Mutsuo; TAKAHASHI, Kazuyuki; TAKAMI, Katsutoshi. Kenpo II [Constitution II]. Tokyo: Yuhikaku, 2012. p. 63.

90 NIHONKOKU KENPO[KENPO][CONSTITUTION], Art.43.

91 Kokkai hou [The Diet Act] Art. 109-2 (Japan).

Koshoku senkyo hou [Japanese Public Officer Election Act], Law No. 60 of 2015. (Japan), Art.99-2 (Japan).

92 NONAKA, Toshihiko; NAKAMURA, Mutsuo; TAKAHASHI, Kazuyuki; TAKAMI, Katsutoshi. Kenpo II [Constitution II]. Tokyo: Yuhikaku, 2012. p. 64-66.

93 Saiko Saibansho [Sup.Ct] April 14, 1976, Showa 49 (gyo tsu) no.75, 30 (3) Saiko Saibansho Minji Hanreishu [Minshu] 223.

94 NIHONKOKU KENPO[KENPO][CONSTITUTION], Art.43.
} 
this case, the disparity of one to five (1 to 4.99) was unconstitutional under Article 14 of the Constitution.

The Supreme Court stated that even though it was unconstitutional, the outcome of the election would not be unconstitutional immediately. Exact equality was not feasible, and under Article 43 (2) and Article 47, electoral districts, methods of voting, and other matters pertaining to the method of election of members of both Houses would be fixed by law.

The appendix of the Public Officer Election Act provides allocation of the members of the Houses, and is inseparable from other provisions, and unconstitutional as a whole.

The factors to be considered included the existing achievement of the election, unity as an electoral district, administrative ward of municipalities, size of area, population density, resident configuration, transportation conditions, and geographical circumstances. It would be held unconstitutional if corrective action was not implemented within "a reasonable period."

The 1976 Court adopted for the first time the Iken-Jotai condition doctrine ruling by invoking Article 31(1 $)^{95}$ of the Administrative Case Litigation Act in case of action for revocation of administrative decision. It is an application by analogy. It is called Jijo Hanketsu. The 1976 decision neglected that Article 219 of the Public Officer Election Act clearly prohibited application of Article 31(1) of the Administrative Case Litigation Act.

According to the Supreme Court, although Article 31(1) was prohibited from applying to the election litigation in Article 219 of the Public Officer Election Act, ${ }^{96}$ by applying the fundamental principle implied in the Administrative Case Litigation Act, an unfair election outcome would be avoided.

Statutes ruled as unconstitutional were declared null and void. Members chosen by an unconstitutional election were non-members in the beginning. The statutes according to which this member joined would be questioned in terms of their effectiveness. The existence of members would be subject to public election suits in many districts.

Supremacy provision in Article 98 (2) of the Constitution did not allow this interpretation in cases that had such significant unconstitutional defects. Declaring this election unconstitutional did not correct the unconstitutional condition and unsuitable outcomes would arise.

\footnotetext{
95 Gyousei Jiken Soshou Hou [Administrative Case Litigation Act], Law No. 59 of 2015 (Japan), Art.31 (Japan). In an action for the revocation of an administrative disposition, the court may dismiss a claim with prejudice on the merits in cases where the original administrative disposition or administrative disposition on appeal is illegal but the revocation thereof is likely to seriously affect public welfare, if the court, having considered the extent of any possible damage to be suffered by the plaintiff, the extent and method of compensation for or prevention of such damage and all other circumstances concerned, finds that the revocation of the original administrative disposition or administrative disposition on appeal is not in line with public welfare. In this case, the court shall declare the illegality of the original administrative disposition or administrative disposition on appeal in the main text of the judgment of dismissal.

96 Koshoku Senkyo Hou [Japanese Public Officer Election Act], Law No. 60 of 2015, Art.219 (Japan).
} 
In 1985, the Supreme Court held unconstitutional the disparity of the members of the House of Representatives under Article 14 and 44 of the Constitution. Its disparity was 1 to 4.40. Invoking the 1976 decision, the outcome of the election was unconstitutional, but held as valid.

The 1976 and 1985 decisions have raised several important issues. First, the 1976 and 1985 decisions illustrated several factors for judicial review, such as the existing achievement of elections, unity as an electoral district, the administrative wards of municipalities, sizes of areas, population density, resident configuration, transportation conditions, and geographical circumstances. It is not clear which factor was emphasized. The Supreme Court left some legislative discretion. The 1976 decision limited the wide discretion of the legislature, but later decisions might have endorsed a rather wide discretion. ${ }^{97}$ These decisions illustrate the distress of the judiciary. Its decisions are based on the large rural-urban shift of population for economic growth in Japan. ${ }^{98}$

Second, the reasonable period is unclear. It encourages the Diet to implement a revision of the electoral district. The explanation is so vague that the legislature would only make small modifications and reforms, rather than drastic overhauls.

Committees in the Houses of the Diet act as advisory bodies, with no legal binding power over the legislature, which is the sole and "the highest organ of state power, and shall be the sole law-making organ of the State," under Article 41 of the Constitution.

Third, the representative may feel th e duty to revise electoral districts in line with decisions made by the Supreme Court, but the political party is financially strong enough to influence candidates in campaigns, and the party may force its members to follow the party's decisions. The party may change its platform after an election, and some representatives may believe that this is a betrayal to voters.

Fourth, the existing electoral system works to the advantage of incumbents. ${ }^{99}$

Fifth, the prime minister's leadership advances reform of the electoral district. The leadership of the prime minister who is also head of the ruling party is strong. The national census is taken every 10 years, ${ }^{100}$ and the district-fixing council of the House of Representatives uses this data. ${ }^{101}$ Usually a revision of the number of members is based on its data.

\footnotetext{
97 WATANABE, Yasuyuki. Rippousha niyoru Seido Keisei to sono Genkai. Hosei kenkyu or Journal of law and politics, Fukuoka, vol. 76, n. 3, 2009.

98 MAKI, John. Pacifism, Popular Sovereignty, and Human Rights. In: LUNEY, Percy; TAKAHASHI, Kazuyuki (Eds.). Japanese Constitutional Law. Tokyo: University of Tokyo Press, 1993.

99 MATSUI, Shigenori. Kenpo [Constitution of Japan]. Tokyo: Yuhikaku, 2007. p. 53. He focuses on limitation if the campaigning.

100 Toukei Hou [Statistics Act], Law No. 53 of 2007, Art.2, 5, 8 (Japan).

101 Shugiin Giin Senkyoku Kakutei Singikai Secchi hou [Law for establishment of electoral district-fixing council for the House of Representatives], Law No. 95 of 2012, Art.3 (Japan).
} 
After the national census in 2000, former prime minister Junichiro Koizumi followed a proposal of five plus five minus by the district-fixing council ${ }^{102}$ of the House of Representatives, and submitted to the Diet a revision of the Public Officer Election Act. His leadership was effective.

In February 2016, in the budget committee in the House of Representatives, Yoshihiko Noda, the former prime minister who lost in the election of 2012, mentioned to Prime Minister Abe that electoral reform was a condition of the dissolution of the House of Representatives in December 2012, which Abe has not yet achieved. Abe answered that the reform should be achieved by the end of 2016 . Several members of the LDP opposed Abe's answer, but his leadership went on for reform. This is because in the Japanese parliamentary system, the prime minister has the power to appoint a minister under Article 68 of the Constitution. This power will work for the prime minister's leadership unless a strong political faction prevents it inside the ruling political party.

Sixth, the district-fixing council is an autonomous third party panel, independent of the legislature. The autonomy of this council might be constitutionally required, and the Supreme Court may emphasize its constitutional importance in its decision before making a declaration of unconstitutionality. The composition of this council may lack legitimacy compared to the legislature chosen directly by voters.

Seventh, equality under Article 14 of the Japanese Constitution requires one to less than two disparities. Constitutional scholars believe that the judiciary is required to achieve this standard. Inferior courts in Japan have the power of judicial review under Article 81 in the National Police Reserve case in 1953. ${ }^{103}$ Before the 2015 Supreme Court decision for voting disparity, some inferior courts rendered disparity as unconstitutional. The Hiroshima High Court held that its unconstitutional decision would take effect after a certain time. Usually unconstitutional decisions are retroactive. The Hiroshima High Court limited the scope of the unconstitutional decision in time base. ${ }^{104}$

The Supreme Court has a duty to render uniform decisions by examining inferior court decisions. Frustrated decisions by inferior courts might induce the Supreme Court to be more positive these days. By emphasizing the autonomy of the council to fix electoral districts in judiciary decisions, the Supreme Court still has room to encourage legislative movement. Otherwise, it may declare legislative decisions unconstitutional.

Lastly, the 1976 decision based on reform of the House of Councillors was not enacted in 1982 nor 1994.Thus, the scope of the 1976 decision was narrow.

\footnotetext{
102 Five plus and five minus, and reformed 68 electoral districts in 20 prefectures.

103 Saiko Saibansho [Sup.Ct] Oct.8, 1952, Showa 27 (ma) no.23, 6 (9) Saiko Saibansho Minji Hanreishu [Minshu]783.

104 Hiroshima Koto Saibansho [Hiroshima High Ct.] March 25, 2013, Heisei 24 (Gyo ke) no. 4, 2185 HANREIJIHOU [HANJI] 36.
} 


\subsection{The $\mathbf{2 0 0 5}$ decision for voting rights outside of Japan}

One of the obstacles for an unconstitutional decision for voting disparity is legislative discretion to amend electoral districts through statutes. The council advice has no legal force. Emphasizing the value of voting rights over the electoral system or institution by legislature means that basic principles of voting rights may tighten legislative discretion.

The Supreme Court admitted that voting rights are limited as long as it is necessary to achieve fairness in elections. In the case that the right to vote is an issue for subjective litigation (Shukan Soshou), the judiciary may narrow legislative discretion. In the case of disparity in voting rights in objective litigation (Kyakkan Soshou), the judiciary will wait for the legislature to work.

The 2005 Supreme Court decision ${ }^{105}$ did not use the term legislative discretion. Before the 2005 decision, the Public Officer Election Act ${ }^{106}$ completely precluded Japanese citizens who were residing abroad with no address in any area of a municipality in Japan from voting in national elections at the time of the general election for members of the House of Representatives held on October 20, 1996. Japanese people brought suit against the government according to the State Redress Act (Kokka Baishou Hou).$^{107}$

In 2005, the Supreme Court held that ex-Article 21(2) and Article 8 of the Supplementary Provisions of the Public Officer Election Act was in violation of Article 15(1) and (3), Article 43(1), and Article 44 of the Constitution for the reason that "limits, for the time being, the applicability of the system for allowing Japanese citizens who were residing abroad and had no address in any area of a municipality in Japan to vote in national elections of Diet members under the proportional representation system will, at least at the time of the first general election of members of the House of Representatives or regular election of members of the House of Councillors to be held after this judgment is handed down, be in violation of Article 15(1) and (3), Article 43(1), and the proviso of Article 44 of the Constitution." ${ }^{108}$

This 2005 decision allowed legal suit to seek declaration on legal relations under public law that "Japanese citizens who are residing abroad and have no address in any area of a municipality in Japan are eligible to vote in an election of members under the single-seat constituency system in the next general election of members of the House of Representatives and in an election of members under the constituency system in the

\footnotetext{
105 Saiko Saibansho [Sup.Ct] September 14, 2005, Heisei 13 (Gyo tsu) no.82, 83, (Gyo Hi) no.76, 77, 59(7) Saiko Saibansho Minji Hanreishu [Minshu] 2087.

106 Koshoku Senkyo Hou [Japanese Public Officer Election Act], Law No. 47 of 1998, Art.21(2), 42, 8 of the supplementary provisions (Japan).

107 Kokka Baishou Hou [The State Redress Act], Law No. 125 of October 27, 1947, Art.1 (Japan).

108 supra note 104.
} 
next regular election of members of the House of Councillors on the grounds that they are listed on the overseas electoral register."109

The 2005 decision shows the following reservations for disparity cases. First, voting rights and disparity are based on different articles of the Constitution. For disparity cases and the equal protection provision, Articles 14 and 44 of the Japanese Constitution arose. In the 2005 decision, the Court applied Article 15(1), 15(3), and 43(1) of the Constitution. Disputes regarding equality principles do not always end in rights-based litigation. One explanation is that equality of voting rights is peripheral in Article 14 of the Constitution, and is subject to wider legislative discretion, and rational review may work. ${ }^{110}$ The basic principle of voting rights binds legislative discretion.

Second, these cases had different types of litigations. For disparity cases, the objective litigation (Kyakkan Soshou) legislatively afforded a party to bring suit. For the 2005 case, the Japanese citizens bought suit to seek damages. The promising point in the 2005 decision is that the Supreme Court held the government liable, and was asked to amend the Public Officer Election Act to extend voting rights to Japanese citizens living abroad. The Japanese Supreme Court rarely admits inaction of the legislature to pass the statutes, as the legislature is the highest organ to pass law under Article 41 of the Constitution. ${ }^{111}$ The 2005 decision focused on more than 10 years. In the disparity case, the reasonable time limit did not show a specific period.

Third, the dissenting opinions of Justice Tokuji Izumi in the 2007 decision for political campaign activity in elections for the House of Representatives in 2005 and the 2015 decision regarding the Political Official Election Act were helpful to limit legislative discretion. ${ }^{112} \mathrm{He}$ attempted to explain the 2007 constitutional decision that held the limitation of political campaign for electing the House of Representatives in 2005 as unconstitutional.

In the 2015 decision regarding the Political Official Election Act limiting Japanese citizen living abroad, Justice Tokuji dissented with the majority, which admitted damage under the State Redress Act. ${ }^{113}$ Emotional distress is not appropriate for monetary damage in voting disparity cases. When voting rights of Japanese citizens are

\footnotetext{
109 supra note $104 .$.

110 SHISHIDO, Joji. Kenpo Kaishaku Ron No Ouyou To Tenkai [Development and application of theory of constitutional interpretation]. 2. ed. Tokyo: Nihonhyouronsha, 2014.

111 Saiko Saibansho [Sup. Ct] November 21, 1985, Showa 53 (o) No.1240, 39(7) Saiko Saibansho Minji Hanreishu [Minshu] 1512 (Japan). SATO, Koji. Kenpo [Constitution]. Tokyo: Seibundo, 2011. p. 636-638.

112 Saiko Saibansho [Sup. Ct] June 13, 2007, Heisei 18(gyo tsu) No.176, 61(4) Saiko Saibansho Minji Hanreishu [Minshu] 1617 (Japan). (Tokuji Izumi, J., dissenting). TOKUJI, Izumi. Watashi No Saikousaibansho Ron [My perspective on the Supreme Court]. [s.I.]: Nihonhyouronsha, 2013. See also, TOMATSU, Hidenori. Equal Protection of the Law. In: LUNEY, Percy; TAKAHASHI, Kazuyuki (Eds.). Japanese Constitutional Law. Tokyo: University of Tokyo Press, 1993. He argues that by using Iken Jotai doctrine of the Supreme Court led confusion in the high court decisions. MATSUI, Shigenori. Kenpo [Constitution of Japan]. Tokyo: Yuhikaku, 2007. p. 44.

113 Kokka Baishou Hou [The State Redress Act], Law No. 125 of October 27, 1947, Art.1 (Japan).
} 
indiscriminately infringed upon, the judiciary must provide a remedy to correct and restore operation of the democratic political process as much as possible.

The litigation for the State Redress Act in this case was supplementary, and the plaintiff Japanese citizens sought the judiciary to recognize the statute as unconstitutional in its reasoning, and encourage the legislature indirectly to restore voting rights. In this case, the plaintiffs were concerned that the primary litigation might be denied, and included the additional argument of the State Redress Act. Nominal damage is not provided in the Japanese State Redress Act; thus, its argument is inappropriate. If the court accepts monetary claims in this case, the judiciary must accept monetary claims in disparity cases in the future.

In disparity of electoral districts, Article 204 of the Public Office Election Act provides litigation and remedy for voters. Thus, in this case, the plaintiff did not have to bring a damage claim under the State Redress Act if the judiciary accepted claims. The judiciary shall engage with legislative inaction for voting rights causing discrimination. If the judiciary accepts monetary claims, the damages would spread and the burden on taxpayers would increase. Free from this anxiety, the judiciary must correct the disparity of voting rights.

\subsection{The 2015 reform and the Supreme Court decision}

The Supreme Court has announced the Iken-Jotai decision every year since 2011 in the House of Representatives and the House of Councillors.

In 2015, the district-fixing council in the House of the Representatives proposed to use Adams' system to allocate members. With the exception of the Socialist (Shamin) and Communist parties (Kyosan), the opposite parties accepted its advisory opinion of removing ten seats from the House of Representatives. The number of the members of the House of the Representatives will be from 475 to 465.

In a discussion between Prime Minister Abe and former Prime Minister Noda in the budget committee in 2016, Abe insisted that rapid reform would be achieved under Adams' approach by the 2020 national census during the 2016 session. Abe told the Secretary General of the LDP, Sadaguchi Tanigaki ${ }^{114}$, to make proposals within the LDP. It has been difficult to build consensus within the LDP as it represents a majority party in the Diet.

In February 2016, the LDP proposed three plans. First, under the 2015 simple national census, a six-seat will be reduced in single-seat constituencies, and a four-seat reduced in proportionally represented. Second, reform of the electoral district will start

114 Taniguchi got injured by bicycle, and resigned post of the Secretary-General of the Liberal-Democratic Party in 2016. 
after the 2020 formal national census. Detailed measures for reduction were not mentioned in this proposal. ${ }^{115}$

These proposals show that the ruling party impedes reform of the electoral districts since the ruling party has the highest number of incumbent members. The Supreme Court decision seeking abolishment of Hitori Betsuwaku has not come to fruition, as its proposal does not coordinate prefectural disparity. Adams' approach met with strong opposition.

In 2016, the Public Officer Election Act was revised to reduce the number of the members from 475 to 465 , reduced the number of single-seat constituencies from 295 to 289 , and reduced the number of proportionally represented, multiple-seat constituencies by 4 (Hirei Daihyo). These changes will come into effect in 2017.

The new Adams' method will be adopted from the 2020 national census onwards. It aims to increase members of the House of Representatives in large cities, and decrease them in under populated areas. The national census may require 9 increases in the single-seat constituencies, and 15 decreases in the proportionally represented, multiple-seat constituencies.

Prime Minister Abe is currently considering amending the Japanese Constitution. The election of the House of Councillors in July 2015 targeted the issue of Japanese Constitutional amendment. Disparity between the Houses of the Diet remain an important concern for Japanese Constitutional law scholars.

\section{CONCLUSION}

After the Meiji Constitution was amended, the electoral constituencies remained the same. Dialogue between the GHQ and the Japanese government concluded to abolish the House of Lords and privileges of the peers under Article 14 of new Constitution. In spite of a lack history of a federal system, the House of Councillors was established with the intention to limit the power of the lower house. The role of the House of Councillors and the difference between these two Houses were not clearly stipulated in the Japanese Constitution. The Public Officer Election Act provides the details of the electoral system. The Constitution stipulates one vote per person, which was intended to fix the voting disparity.

The Tomabechi decision shows that under the parliamentary system of the new Constitution, the cabinet has the power to dissolve the House of Representatives with Article 7, regarding the Emperor's ritual conduct.

This decision used the political question theory, which is criticized by constitutional researchers. Even though political question theory might be intrinsic to

115 Jimin to Minshin Shuin Senkyo Seido Houan wo sorezore Teishutu [LDP and Minshin party submitted bill for reform of election of the House of Representatives], NHK News Web (April 15, 2016). 
democracy, in that voters should be the judges of the cabinet and parliament, the scope and conditions should be clear. In the case of the dissolution of the House of Representatives, unlike the Sunagawa decision, the autonomy and discretion of the cabinet should have been considered.

There should be some clear conditions that stipulate when the dissolution of the House of Representatives is necessary, such as important bills being shelved, fundamental changes occurring in the cabinet, etc. Moreover, whether dissolution of the cabinet can be approved by voters via election is another matter in the Japanese Constitution that needs to be clarified.

There have been several electoral reforms made under the Japanese Constitution. Under the Japanese Constitution, judicial review is concrete, not abstract. However, the litigation for voting disparity is an exception that the Public Officer Election Act allows to stand.

The Constitution requires the government to fix the voting disparity. In Japan, the two Houses of the Diet have introduced their own reform.

It is very unique to review the technique of Iken-Jotai, or an "unconstitutional state or condition," which is an obscure doctrine used by the Japanese Supreme Court in 1976. It explained that, although an election is valid, it is nevertheless an illegal and unconstitutional process as per the equality doctrine of Articles 14 and 44 of the Japanese Constitution. The 1976 decision showed the large movement in Japan from rural areas to large cities and tried to limit legislative discretion.

The Supreme Court has held Iken-Jotai five times since 2009, three times to the House of Councillors and two times to House of Representatives. These decisions allow legislative discretion to modify the allocation of seats in the Diet. Some reform was made, but not thorough because of the strong objection from parliament.

The factors that limit the wide discretion of the legislature were displayed in these decisions, but it is not clear which factors are critical, such as the existing achievement of elections, unity as an electoral district, the administrative ward of municipalities, the size of an area, population density, resident configuration, transportation conditions, and geographical circumstances.

The reasonable time limit for reform should encourage the legislature to make drastic reform, not endorse small modifications to preserve incumbent seats. Members of the Houses of the Diet may lose electoral regions if reforms are enacted.

The political party is strong enough to enforce some electoral reform because members can make their public commitment along with their party agenda in the Japanese parliament. Emphasis on the political party may enforce party commitment among members while sacrificing the unique character of the House of Councillors, the purpose of which is not written in the text of the Japanese Constitution. The House of Councillors had no political party involvement because its aim used to be regional and 
vocational representation in the beginning of current constitution. Nowadays, the political party is the dominant voice in the two Houses of the Diet even though this is not clearly written in the Constitution. The political party may disguise its agenda through distractions such as tax cuts in its campaign.

For reform of electoral regions, the prime minister's leadership would be helpful, but its exercise depends on political fighting with opposition parties and even within his own party.

In order to understand the Japanese parliamentary system, Sato emphasized that the constituency is at the center of the relationship between the cabinet and the parliament under the people's sovereignty. Takahashi viewed the dissolution of the House of Representatives as a weapon for the parties to destroy each other. Munasue required the House of Councillors to seek accountability from the cabinet.

Representatives in the Japanese parliament are required to consider minority opinion, and deliberate to reflect pluralistic perspectives of the people. The different election system aims to achieve this in both Houses of the parliament.

The district-fixing council (Senkyo Kukaku Shingi linnkai) for the House of Representatives was established under the cabinet office. It is not provided in the Constitution, and its opinion is advisory, with no binding power; that is to say that its advice does not bind the cabinet. The council's autonomy to fix the electoral district might be constitutionally required if the judiciary declares that voting disparity has been unconstitutionally unequal under unconstitutional conditions or states (Iken-Joutai). The judiciary can reflect district council opinion in writing its decisions.

One alternative solution for the judiciary to encourage reform by legislature is the rights-based approach mentioned in the 2005 decision. In this case, the Supreme Court allowed legal suit seeking declaration of legislative inaction under public law for those who live outside of Japan and are unable to vote. Although this decision didn't use the term "legislative discretion," the basic principle of voting right might bind legislative discretion in voting disparity cases.

Justice Tokuji's dissenting opinion in the 2007 decision admitted damage under the State Redress Act. Emotional distress is not appropriate for monetary damage in voting disparity cases. When voting rights of Japanese people are indiscriminately infringed upon, the judiciary must provide a remedy to correct and restore operation of the democratic political process as much as possible.

The litigation for the State Redress Act in this case was supplementary, and the plaintiff Japanese citizens sought the judiciary to recognize the statute as unconstitutional in its reasoning, and indirectly encourage the legislature to restore voting rights.

These voting disparity decisions show the core of the parliament, the constitutionality of the dissolution of the House of Representatives, the constitutional control for electoral reform, and the relationship among the judiciary, legislature, and cabinet. 
The rights-based approach might limit the wide discretion of the legislature. The unique roles of the House of Councillors and political parties were not stipulated in the Japanese Constitution. These factors are now vital in analyzing the Iken-Jotai doctrine in the Japanese Constitution.

\section{REFERENCES}

ASHIBE, Nobuyoshi. Kenpo [Constitution]. 6. ed. Tokyo: Iwanami Shoten, 2015.

ASHIBE, Nobuyoshi. Kenpo to Gikaisei [Constitution and Parliamentary system]. Tokyo: Tokyo University Press, 1971.

BEER, Lawrence. Peace in Theory and Practice under Article 9 of Japan's Constitution. Marquette Law Review, Milwaukee, vol. 81, n. 3, p. 815-830, mar./may 1998.

HALEY, John. The Spirit Of Japanese Law. Athens: University of Georgia Press, 2006.

HIGUCHI, Youichi. Hikaku Kenpo [Comparative Constitution] 3. ed. [s.I.]: Seirin Shoin, 1992.

KAMATA, Taisuke. Adjudication and the Governing Process; Political Questions and Legislative Discretion. In: LUNEY, Percy; TAKAHASHI, Kazuyuki (Eds.). Japanese Constitutional Law. Tokyo: University of Tokyo Press 1993.

KATO, Kazuhiko. Sangi-in no Isikika sareta Genzo Keisei. Tokyo Keizai Law Review, Tokyo, vol. 30, p. 199-?, 2016.

MAKI, John. Pacifism, Popular Sovereignty, and Human Rights. In: LUNEY, Percy; TAKAHASHI, Kazuyuki (Eds.). Japanese Constitutional Law. Tokyo: University of Tokyo Press, 1993.

MATSUI, Shigenori. Kenpo [Constitution of Japan]. Tokyo: Yuhikaku, 2007.

NONAKA, Toshihiko; NAKAMURA, Mutsuo; TAKAHASHI, Kazuyuki; TAKAMI, Katsutoshi. Kenpo II [Constitution II]. Tokyo: Yuhikaku, 2012.

RAMSEYER, Mark; RASMUSEN, Eric. Measuring Judicial Independence: the political economy of judging in Japan. Chicago: University of Chicago Press, 2003.

SATO, Isao. Pokeet Kenpo [Pocket Constitution]. vol. 1. Tokyo: Yuhikaku, 1983.

SATO, Isao. Pokeet Kenpo [Pocket Constitution]. vol. 2. Tokyo: Yuhikaku, 1984.

SATO, Koji. Kenpo [Constitution]. Tokyo: Seibundo, 2011.

SHISHIDO, Joji. Kenpo Kaishaku Ron No Ouyou To Tenkai [Development and application of theory of constitutional interpretation]. 2. ed. Tokyo: Nihonhyouronsha, 2014.

SOUICHI, Sasaki. Nihon Kenpou Youron [The main theory of Constitution]. 3. ed. [s.I.]: Kanasashi Houryudou, 1933.

TADANO, Masahito. The Right to vote and equality of value of vote. [s.I.]: Zenkoku Kenou Kenkyukai, 2015. 
TAKAHASHI, Kazuyuki. Contemporary Democracy in a Parliamentary System. In: LUNEY, Percy; TAKAHASHI, Kazuyuki (Eds.). Japanese Constitutional Law. Tokyo: University of Tokyo Press, 1993.

TAKAHASHI, Kazyuki. Rikkenshugi To Nihonkokukenpo [Constitutionalism and the Constitution of Japan] Tokyo: Yuhikaku, 2013.

TANAKA, Hideo. A History of the Constitution of Japan of 1946. In: TANAKA, Hideo; SMITH, Malcolm (Eds.). The Japanese Legal System. Tokyo: University of Tokyo Press, 1976.

TATSUKICHI, Minobe. Kenpo Teiyou [Constitution]. 5. ed. Tokyo: Yuhikaku, 1932.

TOKUJ, Izumi. Watashi No Saikousaibansho Ron [My perspective on the Supreme Court]. [s.l.]: Nihonhyouronsha, 2013.

TOMATSU, Hidenori. Equal Protection of the Law. In: LUNEY, Percy; TAKAHASHI, Kazuyuki (Eds.). Japanese Constitutional Law. Tokyo: University of Tokyo Press, 1993.

TSUJ, Yuichiro. Amendment of the Japanese Constitution - A Comparative Law Approach. Nanzan Review of American Studies, Aichi, vol. 37, p. 51-70, 2015.

TSUJ, Yuichiro. Article 9 and the History of Japan's Judiciary: Examining Its Likeness to American and German Courts. Tsukuba Journal of Law and Politics, Tsukuba, vol. 68, p. 35-78, oct. 2016.

TSUJ, Yuichiro. Constitutional Court in Japan. Tsukuba Journal of Law and Politics, Tsukuba, vol. 66, p. 65-87, mar. 2016.

TSUJIMURA, Miyoko. Note sur la theone du "mandat imperatif". [s.I.]: Hitotsubashi Kenkyu, 1977.

TSUJIMURA, Miyoko. Simin Shuken no Kanousei [Possibility of citizen sovereignty]. Tokyo: Yushindo, 2002.

WATANABE, Yasuyuki. Rippousha niyoru Seido Keisei to sono Genkai. Hosei kenkyu or Journal of law and politics, Fukuoka, vol. 76, n. 3, 2009. 